\title{
Effect of double dose oseltamivir on clinical and virological outcomes in children and adults admitted to hospital with severe influenza: double blind randomised controlled trial
}

\author{
(c) $\underset{\text { (1) (8) }}{\text { gy }}$ OPEN ACCESS
}

South East Asia Infectious Disease Clinical Research Network

\author{
Abstract \\ Objective To investigate the validity of recommendations in treatment \\ guidelines to use higher than approved doses of oseltamivir in patients \\ with severe influenza. \\ Design Double blind randomised trial. \\ Setting Thirteen hospitals in Indonesia, Singapore, Thailand, and \\ Vietnam.
}

Participants Patients aged $\geq 1$ year admitted to hospital with confirmed severe influenza.

Interventions Oral oseltamivir at double dose (150 mg twice a day/paediatric equivalent) versus standard dose (75 $\mathrm{mg}$ twice a day/paediatric equivalent).

Main outcome measure Viral status according to reverse transcriptase polymerase chain reaction (RT-PCR) for influenza RNA in nasal and throat swabs on day five.

Results Of 326 patients (including 246 (75.5\%) children aged < 15), 165 and 161 were randomised to double or standard dose oseltamivir, respectively. Of these, $260(79.8 \%)$ were infected with influenza virus A (133 (40.8\%) with A/H3N2, 72 (22.1\%) with A/H1N1-pdm09, 38 (11.7\%) with seasonal $\mathrm{A} / \mathrm{H} 1 \mathrm{~N} 1,17(5.2 \%)$ with $\mathrm{A} / \mathrm{H} 5 \mathrm{~N} 1)$ and $53(16.2 \%)$ with influenza virus B. A further $3.9 \%$ (13) were false positive by rapid antigen test (negative by RT-PCR and no rise in convalescent haemagglutination inhibition titers). Similar proportions of patients were negative for RT-PCR on day five of treatment: $115 / 159(72.3 \%, 95 \%$ confidence interval $64.9 \%$ to $78.7 \%)$ double dose recipients versus $105 / 154(68.2 \%, 60.5 \%$ to $75.0 \%$ ) standard dose recipients; difference $4.2 \%$ ( -5.9 to 14.2 ); $P=0.42$. No differences were found in clearance of virus in subgroup analyses by virus type/subtype, age, and duration of illness before randomisation. Mortality was similar: $12 / 165(7.3 \%, 4.2 \%$ to $12.3 \%)$ in double dose recipients versus $9 / 161$ (5.6\%, 3.0\% to $10.3 \%$ ) in standard dose recipients. No differences were found between double and standard dose arms in median days on supplemental oxygen (3 (interquartile range 2-5) $v 3.5(2-7))$, in intensive care $(4.5(3-6) v 5$ (2-11), and on mechanical ventilation $(2.5(1-16) v 8(1-16))$, respectively. No important differences in tolerability were found.

Conclusions There were no virological or clinical advantages with double dose oseltamivir compared with standard dose in patients with severe influenza admitted to hospital.

Registration Clinical Trials NCT00298233

\section{Introduction}

Human influenza is often considered an acute self limiting febrile illness. Occasionally, however, it is associated with respiratory complications, admission to hospital, and mortality. ${ }^{1-3}$ Clinical trials have shown that treatment with oseltamivir has clinical and virological benefit in patients with uncomplicated influenza when it is administered within 48 hours of onset of symptoms. ${ }^{4-7}$ Randomised trials in patients with severe influenza are lacking, but observational studies in patients admitted to hospital indicate that oseltamivir treatment, especially if it is given early, is associated with reduced mortality and shorter length of stay, although mortality can still be up to $6 \%$ with H1N1-pdm09 (pandemic A/H1N1 2009 influenza) or seasonal influenza. ${ }^{8-12}$ Timely oseltamivir treatment of patients with avian H5N1 influenza reduces mortality, but many patients die despite treatment.

Higher oseltamivir doses were tested in patients with uncomplicated influenza, but no consistently improved clinical or virological outcomes were found compared with the standard dose. ${ }^{41314}$ Despite a lack of evidence, several authorities have suggested use of double dose oseltamivir for severe influenza. ${ }^{15-17}$ The use of higher doses has major implications for clinical management, public health, and planning for antiviral stockpiles. The sudden emergence of pandemic H1N1 virus in 2009, the persistent circulation of highly pathogenic avian $\mathrm{H} 5 \mathrm{~N} 1$ viruses across large regions of the world since 1997, and the recent emergence and spread of avian H7N9 influenza virus in China ${ }^{18}$ 
illustrate the continuing threat of influenza viruses to global health. Improvement of the evidence base for current treatment guidelines of severe influenza is clearly essential for optimal clinical management and pandemic preparedness. Consequently, we conducted a randomised controlled trial to ascertain whether double dose oseltamivir controls viral replication faster and improves clinical outcomes compared with standard dose in patients admitted to hospital with severe influenza.

\section{Methods}

\section{Study design and sites}

This was a prospective, multicentre, double blinded, randomised trial of standard dose oseltamivir $(75 \mathrm{mg}$ twice a day or paediatric equivalent) versus double dose (150 mg twice a day or paediatric equivalent) for treating severe influenza. The study took place between April 2007 and February 2010 in 13 hospitals in Indonesia, Singapore, Thailand, and Vietnam.

\section{Participants}

The inclusion criteria were age $\geq 1$ year, respiratory illness with duration of symptoms $\leq 10$ days, laboratory confirmed influenza, and either evidence of severe influenza (defined below) or positive result of a diagnostic test for H5N1. Severe influenza was defined as admission to hospital and one of the following: new infiltrate on chest $x$ ray; tachypnoea (respiratory rate $\geq 30$ for ages $\geq 12, \geq 40$ for ages $6-11, \geq 45$ for ages $3-5, \geq 50$ for ages $1-2$ ); dyspnoea; or hypoxia (arterial oxygen saturation $\leq 92 \%$ on room air). Exclusion criteria were pregnancy or positive for chorionic gonadotrophin (hCG) in urine, women who were actively breast feeding, a delay of more than 72 hours before treatment with oseltamivir, and severe renal impairment defined by creatinine clearance $<10 \mathrm{~mL} / \mathrm{min}$ (Cockcroft-Gault equation).

\section{Treatment}

Patients were randomised to receive double or standard dose oseltamivir based on a computer generated list that was stratified by site and age group. Patients with H5N1 influenza were stratified separately.

Oseltamivir capsules, paediatric oseltamivir suspensions, and placebo suspensions were provided by Roche (Basel,

Switzerland). Placebo capsules were manufactured by the pharmaceutical development section at the National Institutes of Health Clinical Center (Bethesda, MD, US). The doses were $75 \mathrm{mg}$ or $150 \mathrm{mg}$ twice daily in those aged $\geq 15$ or weighing $>40 \mathrm{~kg} ; 60 \mathrm{mg}$ or $120 \mathrm{mg}$ twice daily in those weighing $>23-40$ $\mathrm{kg}$; $45 \mathrm{mg}$ or $90 \mathrm{mg}$ twice daily in those weighing $>15-23 \mathrm{~kg}$; and $30 \mathrm{mg}$ or $60 \mathrm{mg}$ twice daily in those weighing $\leq 15 \mathrm{~kg}$. These doses were halved for patients with a creatinine clearance $\geq 10$ and $<30 \mathrm{~mL} / \mathrm{min}^{17}{ }^{19}{ }^{20}$ All drug treatments were supervised by the research team.

All patients received five days of oseltamivir. Those with persistent tachypnoea, dyspnoea, or hypoxia on day five of the study were defined as meeting the criteria for clinical failure and continued to take the randomised dose for an additional five days.

\section{Study evaluations}

Patients with severe influenza-like illness were screened with the Quickvue rapid test (Quidel, San Diego, CA, US) and/or reverse transcriptase polymerase chain reaction (RT-PCR) of throat and nose swabs. Patients with positive results for influenza virus who met the inclusion criteria were randomised. Swabs were obtained for virus detection in the nose and throat on days
0 to 10 and day 14 . Study swabs were collected and eluted in M4 media (Remel, Lenexa, KS, US) before storage at $-70{ }^{\circ} \mathrm{C}$.

\section{Virology}

Testing of the combined nasal and throat swab specimens on day five, which was the primary virological study endpoint, was done under blinded conditions in the SEAICRN reference laboratories in Vietnam and Indonesia. Qualitative RT-PCR for detection of influenza A and B viruses and for subtyping of influenza A viruses was done according to WHO/US CDC protocols. ${ }^{21}{ }^{22}$ Quantitative RT-PCR for influenza virus A and $\mathrm{B}$, with a lower limit of quantification of $10^{3}$ copies of cDNA per $\mathrm{mL}$, was performed as described previously. ${ }^{23}$ Virus culture and genotypic screening for oseltamivir resistance mutations were performed as described previously on day 0 samples for all enrolled patients and on day five samples for patients with positive results on RT-PCR. ${ }^{24} 25$

\section{Data analysis Endpoints}

The primary efficacy endpoint was the proportion of all patients with no detectable viral RNA by RT-PCR in a combined nasal and throat swab sample on day five. We also examined numerous secondary clinical endpoints (such as mortality, mechanical ventilation, admission to intensive care, symptoms, resumption of activity) and virological endpoints. We chose the proportion of patients with viral RNA shedding at day five after the start of treatment as the primary endpoint as this represents the duration of one standard course of oseltamivir and clinical failure is generally evaluated after five days of treatment. This is also consistent with the 2010 position paper by Ison and colleagues on the choice of efficacy endpoints in severe influenza studies. ${ }^{26}$

\section{Sample size calculations}

Based on previous studies, we assumed that children and adults admitted to hospital with influenza would have detectable virus for an average of 6.3 days (plus or minus 1.5 days) and 4 days after onset of treatment, respectively. ${ }^{26-28}$. If we assume that $30 \%$ of children and $55 \%$ of adults treated with standard dose oseltamivir would test negative for virus on day five, a sample size of 242 patients would be required to show a $20 \%$ absolute improvement in cessation of viral shedding with $85 \%$ power and a two sided $\alpha$ of 0.05 . To allow for study withdrawals, our target sample size was 300 patients.

\section{Statistical analyses}

Data were analysed with Stata v10 (Stata Corporation, Washington DC). The intention to treat population included all patients randomised, whether or not they received study drug.

For the virological endpoints, we included only patients with RT-PCR proved influenza virus infection on screening (day 0). Patients who died before day five were assumed to be virus positive on day five unless the virus was cleared before death. For patients with missing results on day five, we carried forward the last available results.

We used conditional univariate logistic regression to calculate and compare the odds ratios of viral clearance for categorical data between the treatment arms stratified by study site and the Mantel-Haenszel method when the numbers of patients were small. The Breslow-Day test was used to test the heterogeneity of the results between study sites. Because we found no heterogeneity, we used conditional multiple logistic regression 
to investigate independent predictors of viral RNA clearance on day five, stratified by study sites. In these regression models, the quantifiable viral load data were used (that is, $\geq 10^{3} \mathrm{cDNA}$ copies $/ \mathrm{mL}$ ) and data from samples positive by qualitative RT-PCR but not quantifiable were given a value of $10^{3} \mathrm{cDNA}$ copies(c)/mL, the lower limit of detection of the quantitative RT-PCR. This analysis was repeated by giving these samples the value of 0 .

For multiple regression we forced important variables such as age group, (sub)type of virus, and treatment arm in the model, while for other factors we used forward stepwise variable selection procedure with $5 \%$ significance. Normally distributed continuous data were compared between the two arms with the unpaired $t$ test; the Mann-Whitney U or Kruskal-Wallis tests were used for skewed data. For all comparative analyses, $\mathrm{P}<0.05$ was considered significant. All P values are two tailed.

Confidence intervals for proportions and their differences were calculated with Wilson's method.

\section{Results}

\section{Patients' characteristics}

Between April 2007 and February 2010, 699 patients were screened and 326 were enrolled and randomised: 165 received double dose and 161 standard dose oseltamivir. The figure shows the flow of patients through the trial $\downarrow$. Most patients were children $(246 / 326,75.5 \%)$ aged $1-13.5$, median 2 years (table $1 \Downarrow)$. Enrolment differed by country: $235(72.1 \%)$ were from Vietnam, 71 (21.8\%) from Thailand, 15 (4.6\%) from Indonesia, and five (1.5\%) from Singapore.

In total, 260 (79.8\%) patients were infected with influenza virus A (133 (40.8\%) with A/H3N2, 72 (22.1\%) with A/H1N1-pdm09, $38(11.7 \%)$ with seasonal $\mathrm{A} / \mathrm{H} 1 \mathrm{~N} 1$, and $17(5.2 \%)$ with $\mathrm{A} / \mathrm{H} 5 \mathrm{~N} 1)$ and $53(16.2 \%)$ with influenza virus B. A further $13(3.9 \%)$ were positive by rapid antigen test but negative by RT-PCR. The latter were confirmed as false positive tests as there was no rise in haemagglutination inhibition titers during convalescence. All patients with $\mathrm{H} 5 \mathrm{~N} 1$ met criteria for severe influenza and were therefore analysed as such.

Patients were enrolled a median of 5 (range 1-10) days after the onset of illness: 7 (3-11) days for patients with H5N1 infected and 5 (1-10) days in other patients $(\mathrm{P}<0.001)$. A minority of patients, 76/326 (23.3\%) had been prescribed oseltamivir or zanamivir before enrolment, and most 231/326 (70.8\%) had received antibiotics. At enrolment, $57(17.5 \%)$ patients needed immediate admission to intensive care, of whom 34 (10.4\%) required mechanical ventilation, and $25(7.7 \%)$ had acute respiratory distress syndrome (table 1 ). $\Downarrow$

Baseline rates of positivity for RNA influenza were similar for the nasal $(239 / 317,75.4 \%)$ and throat $(242 / 312,77.6 \%)$ swabs. Median baseline quantitative viral loads were similar between the two arms for nose $(9.6 \times 10 \mathrm{e} 4$ copies in the double dose $(n=99)$ and $1.5 \times 10 \mathrm{e} 5$ copies in the standard dose arm $(n=96))$ and throat $(4.1 \times 10 \mathrm{e} 4$ copies in the double dose $(\mathrm{n}=85)$ and $6.3 \times 10 \mathrm{e} 4$ copies in the standard dose arm $(n=95)$; see supplementary figure in appendix).

\section{Primary virological efficacy endpoint Day five negative viral RNA by RT-PCR}

At day five, the proportions of all patients negative for viral RNA in the nasal and throat swabs were similar between the double $(115 / 159 ; 72.3 \%$, $95 \%$ confidence interval $64.9 \%$ to $78.7 \%)$ and standard dose arms $(105 / 154 ; 68.2 \%, 60.5 \%$ to $75.0 \%)$, with a difference of $4.2 \%$ ( $-5.9 \%$ to $14.2 \%$; $\mathrm{P}=0.42)$.
In children, the corresponding rates were $71 \%(85 / 120 ; 62.2 \%$ to $78.2 \%)$ in the double dose arm versus $67 \%(79 / 118 ; 58.0 \%$ to $74.8 \%)$ in the standard dose arm $(\mathrm{P}=0.52)$, and in adults $77 \%$ ( $30 / 39 ; 61.7 \%$ to $87.4 \%)$ versus $72 \%(26 / 36 ; 56.0 \%$ to $84.2 \%)$, respectively $(\mathrm{P}=0.64)$. Among 64 samples from 83 patients positive for RT-PCR on day five, samples from $6 / 28(21 \%$, $10.2 \%$ to $39.5 \%)$ double dose patients and $5 / 36(14 \%, 6.1 \%$ to $28.7 \%$ ) standard dose patients had infectious virus detected in cell culture $(\mathrm{P}=0.43)$.

Given the heterogeneity of the enrolled population, we performed post hoc exploratory analyses to evaluate detection and quantification (copy numbers) of virus RNA on day one, three, and five of treatment in several subgroups of interest (age, virus, days of illness before enrolment). There were no significant differences between the arms in any of the subgroups on day five (tables 2 and $3 \Downarrow \downarrow$ ). In addition, no comparisons showed less frequent virus RNA detection in the double dose group on treatment day one or three in any subgroup of interest (data not shown).

Specifically, at day five, in the 224 patients infected with seasonal influenza (excluding H5N1 and H1N1-pdm09 infections) the proportions of patients with negative results for viral RNA in the nasal and throat swabs were similar $(\mathrm{P}=0.45)$ between the double $(82 / 114,72 \%)$ and standard dose arms (74/110, 67\%). In children, the corresponding rates were 77/99 (71\%) in the double dose versus 62/94 (66\%) in the standard dose arm $(\mathrm{P}=0.48)$, and in adults $12 / 15(80 \%)$ versus $12 / 16$ $(75 \%)$, respectively $(\mathrm{P}=0.74)$. Given the detected rates of viral shedding at day five this sample of 224 patients has more than $85 \%$ power to show a $20 \%$ absolute improvement in cessation of viral shedding at two sided $\alpha$ of 0.05 .

After day five, the proportions of patients positive for RNA in the double and standard dose arms declined but were similar. In nasal samples by day 10, 4/138 (2.9\%) and 4/132 (3.0\%) patients remained positive for viral RNA in double and standard dose arms. In throat samples these proportions were 13/137 $(9.5 \%)$ and $15 / 130(12 \%)$, respectively $(\mathrm{P}=1.00$ for nose and $\mathrm{P}=0.59$ for throat for comparison between arms); corresponding proportions for day 14 were $0 / 15$ and $0 / 13$ for nose and $1 / 15$ and $1 / 13$ for throat.

In the conditional multiple logistic regression analysis (table $4 \Downarrow$ ), patients who had no viral RNA detected on day five were more likely to have lower nasal viral loads at baseline, human (non-avian H5N1) influenza virus infection, and a higher Karnofsky score $(\geq 50){ }^{29}$

Duration of illness before enrolment and antiviral treatment before enrolment were not significant predictors in the multivariate model: odds ratio 1.48 (95\% confidence interval 0.79 to $2.80 ; \mathrm{P}=0.22$ ) for duration of illness over two days and $1.53(0.51$ to $4.55 ; \mathrm{P}=0.45)$ for antiviral treatment.

\section{Secondary endpoints Day five clinical failure}

The criteria for clinical failure on day five were met in 16/161 (9.9\%, $95 \%$ confidence interval $6.2 \%$ to $15.5 \%)$ patients in the double dose and $20 / 158(13 \%, 8.3 \%$ to $18.7 \%)$ in the standard dose $\operatorname{arm}(\mathrm{P}=0.44)$; all received five additional days of oseltamivir. There were also no differences in clinical failure in the subgroup of patients with seasonal influenza viruses (see above): $3 / 114(2.6 \%, 0.9 \%$ to $7.5 \%)$ patients in the double dose and $5 / 110(4.5 \%, 2.0 \%$ to $10.2 \%)$ in the standard dose arm $(\mathrm{P}=0.50)$. Of 17 patients infected with avian $\mathrm{H} 5 \mathrm{~N} 1$ virus, only three survived to the day five evaluation, all of whom met the criteria for clinical failure. Persistent detection of viral RNA on 
day five was found in $17 / 34(50 \%, 34.1 \%$ to $65.9 \%)$ of patients meeting criteria for clinical failure on day five compared with $75 / 275$ (27\%, $22.3 \%$ to $32.8 \%)$ of patients not meeting criteria for clinical failure $(\mathrm{P}=0.006)$.

\section{Mortality}

The overall case fatality rate was $21 / 326(6.4 \%, 4.3 \%$ to $9.6 \%)$. The 21 deaths occurred at similar rates in the double $(\mathrm{n}=12$; $7.3 \%, 4.2 \%$ to $12.3 \%)$ and standard dose $(n=9 ; 5.6 \%, 3.0 \%$ to $10.3 \%)$ arms $(\mathrm{P}=0.54)$. Most deaths $(15 / 21,71 \%)$ were in patients with avian $\mathrm{H} 5 \mathrm{~N} 1$ virus. The six deaths not related to H5N1 (two with H3N2, one with influenza B, one with H1N1pdm09, and two negative) were not significantly different between arms. Mortality rates for H5N1 by country were similar, with 10/11 (90\%) in Indonesia and 5/6 (83\%) in Vietnam. Median (range) times to death were 2 days (1-12) in those with avian H5N1 and 5.5 days (1-13) days in those with other influenza viruses (table $5 \Downarrow$ ).

\section{Hospital course}

During the study, 98/326 (30.1\%) of all patients required supplemental oxygen, 61/326 (18.7\%) were admitted to intensive care, and 40/326 (12.3\%) required mechanical ventilation. Most of these interventions occurred before or at the time of enrolment. After enrolment, an additional five patients needed supplemental oxygen, four required admission to intensive care, and six were mechanically ventilated. The median durations of these interventions were similar between the two treatment arms (table $6 \Downarrow$ ). Three patients developed acute respiratory distress syndrome $^{28}$ after enrolment across both arms (two double dose, one standard dose).

\section{Use of antibiotics and steroids}

For patients not taking antibiotics at enrolment, antibiotic prescribing was similar $(\mathrm{P}=0.27)$ for both arms after enrolment: $31 / 50(62 \%)$ in the double dose and 33/45 (73\%) in the standard dose arm. Twenty children (10 in each arm) and 10 adults (five in each arm) were given inhaled steroids for bronchospasm.

\section{Adverse events}

Oseltamivir was generally well tolerated; 55 (16.9\%) patients had 75 treatment emergent adverse events with similar rates between the two arms (table $7 \Downarrow$ ). The most common adverse events were respiratory failure $(n=14)$, diarrhoea $(n=11)$, and multi-organ failure $(n=6)$. Overall $14(19 \%)$ adverse events were judged as possibly, probably, or definitely related to oseltamivir. ${ }^{30}$ There was no difference between adults and children in reported adverse events.

\section{Oseltamivir resistance}

No patients with H1N1-pdm09 or H5N1 had the oseltamivir resistance associated mutation $\mathrm{H} 275 \mathrm{Y}$ at baseline or after treatment. Among 38 patients infected with seasonal H1N1 viruses, 32 (11 in double dose arm, 21 in standard dose arm) could be sequenced and 18 (56\%; six double dose, 12 standard dose) of these had the H275Y mutation at baseline. ${ }^{31}$ Among the 14 patients (five in double dose arm, nine in standard dose arm) with an H1N1 virus without this mutation, four out of seven (two double dose, five standard dose) that could be sequenced after day 0 developed the H275Y mutation during treatment (four standard dose). No differences in viral RNA detection rates or outcome were associated with presence of the
H275Y mutation at day 0 or day five among patients infected with seasonal H1N1 viruses, but numbers were small.

\section{Discussion}

In this large randomised controlled trial of antiviral treatment in patients with severe influenza we found that double dose oseltamivir was well tolerated but did not confer additional virological or clinical benefits over standard dose treatment in patients in South East Asia. There were no differences between the treatment arms in detection of viral RNA or infectious virus on day five, and there were also no differences in clinical failure rates, mortality in hospital, or rates of adverse events between the dose regimens on day five. We enrolled a heterogeneous population that included mostly children and also those infected with avian $\mathrm{H} 5 \mathrm{~N} 1$ or H1N1-pdm09 viruses. While subgroup analyses based on age cohorts, virus type and subtype, and time to treatment did not suggest additional virological efficacy of double dose oseltamivir in any subgroup, these results should be interpreted with caution as the study was not powered for these analyses.

Our patients presented relatively late after the onset of illness, a median of five days overall (seven days for H5N1). Despite administration of oseltamivir, about $30 \%$ of those enrolled remained positive for viral RNA (the primary endpoint) after five days of treatment. Timing of oseltamivir treatment is important as several studies have shown that early treatment confers greater virological and clinical benefits. ${ }^{4-6}$ 32-34 In particular, later viral clearance has been noted with delayed treatment with oseltamivir compared with treatment within two to three days after onset of symptoms in observational reports from patients with H1N1-pdm09, especially those with severe illness. ${ }^{35-40}$ In the current trial, $73(22.4 \%)$ patients presented within three days of illness, but even in this subpopulation, double dose oseltamivir was not associated with more rapid viral RNA clearance. Over a quarter of patients received neuraminidase inhibitors before enrolment, which could have influenced the effect size and contributed to the low proportion of patients shedding virus at day five in both treatment groups.

Although viral RNA detection in samples from the upper respiratory tract might not accurately reflect viral replication in the lower respiratory tract, especially in those with severe illness, ${ }^{39}$ prolonged viral RNA detection in upper respiratory tract samples has been shown to correlate with inpatient morbidity and prolonged hospital stay. In our study viral detection on day five was observed at about twofold the frequency in those meeting the criteria for clinical failure, although lack of clinical failure was not a surrogate for cessation of viral detection. Thus in our study the delays in starting treatment with oseltamivir also probably contributed to the substantial rates of admission to intensive care (18\%), use of supplemental oxygen (30\%), mechanical ventilation (12\%), and mortality in hospital of $6.4 \%$. Although our study was not placebo controlled for ethical reasons, other studies indicate that early oseltamivir treatment in people with severe influenza is associated with both clinical benefits and more rapid viral clearance from upper respiratory tract samples. ${ }^{4} 814$ 36-41

\section{Possible reasons for findings}

It is unclear why double dose oseltamivir does not seem to offer benefit over standard dose in patients with severe influenza. Blood trough concentrations of oseltamivir carboxylate from $75 \mathrm{mg}$ or $150 \mathrm{mg}$ twice daily in influenza exceed the $\mathrm{IC}_{50}$ (inhibitory concentration) of influenza viruses. ${ }^{42}{ }^{43}$ Inhibition of viral neuraminidase by oseltamivir might be a saturable process, 
and maximal inhibition might be achieved with a standard dose; exceeding these concentrations might not produce an additional clinical or virological effect. In this regard, a randomised oseltamivir controlled study of intravenous peramivir (BioCryst Pharmaceuticals, Durham, NC), which reaches over 20-fold higher peak blood concentrations of active metabolite than oseltamivir carboxylate, found similar viral reductions in patients with influenza A virus admitted to hospital. ${ }^{44}$ Further studies of peramivir and other intravenous neuraminidase inhibitors currently in progress should provide additional evidence regarding this hypothesis.

Infection with avian H5N1 virus, higher baseline viral load, and severity of disease were independently associated with longer viral RNA detection. The association between avian H5N1, severe illness, and prolonged shedding has been well described. ${ }^{14}$ The clearance kinetics of influenza viruses, both without antiviral treatment and with oseltamivir treatment, ${ }^{32}{ }^{41}$ could explain longer viral RNA detection with higher baseline viral loads. It is unclear whether the independent association with disease severity might be related to impaired mechanisms of viral clearance or higher intrinsic rates of viral replication or both in these patients. Severe chronic comorbidities are seen commonly in industrialised countries and are related to prolonged viral shedding but most of our patients lacked these comorbidities. $^{4041}$

The heterogeneous population characteristics, geographical differences in recruitment (most patients were from Vietnam but there were no significant differences between Vietnam and other sites), and the variety of infecting viruses in our trial reflect the clinical circumstances in South East Asia during our study but might be viewed as a limitation. Most of these patients were children and had low or normal BMI, and for all patients only about a fifth reported a chronic underlying medical condition. Thus, our findings are applicable primarily to the region where the study was conducted and other settings with similar characteristics of influenza epidemiology. We did not have many adults in our study and results were inconclusive but indicate no difference in efficacy between the two oseltamivir regimens. We would caution the extension of our results to, for example, morbidly obese adults with severe influenza and those who could have underlying chronic illnesses. We conducted several statistical comparisons and inevitably subgroup analyses involved small numbers; thus power was limited and some significant results could have resulted by chance. Additionally, as all patients were randomised to an active treatment, our study was not designed to evaluate the efficacy of oseltamivir in severe influenza nor in $\mathrm{H} 5 \mathrm{~N} 1$ infections. This large randomised trial did, however, examine an important clinical and public health question and showed a lack of a clinical or virological benefit of double dose compared with standard dose oseltamivir in patients admitted to hospital with severe influenza. Our results and other observational reports from avian $\mathrm{H} 5 \mathrm{~N} 1{ }^{10}$ and H1N1-pdm09 ${ }^{11}{ }^{36}$ infections do not support routine use of double dose oseltamivir to treat severe influenza. These findings have implications for both clinical management and pandemic preparedness including during the current H7N9 epidemic. ${ }^{16} 1718$

We thank the patients for enrolling themselves and their guardians for granting permission to enrol their children into the study. We dedicate this work to the memory of Endang Rahayu Sedyaningsih, Minister of Health of the Republic of Indonesia 22 October 2009 to 30 April 2012, and Niklas Lindegardh Mahidol, Oxford Research Unit.

We thank the following for their support: Nguyen Thi Dung, Pham Thi Ngoc Dung, Dao Tuyet Trinh, Van Dinh Trang, Nguyen Nhu Ha, Nguyen Thi Dai Phong, Nguyen Thi Kim Yen, Khuat Thi Oanh, Nguyen Thi Hang,
Pham Thi Thanh Hoa, Vu Thi Nham, Nguyen Thi Oanh, Nguyen Hai Van, Nguyen Bang Giang, Duong Thi Hoa, Nguyen Hong Vu, Mai Thi Hong Hanh, Dang Thi Thu Hang, Tran Thi Sinh, Ngo Thi Hoa, Phung Thi Bich Thuy, Pham Thi Thanh Hoa, Nghiem Thi Tuyet, Do Quang Vi, Nguyen Trung Hang, Nguyen Thi Hong Ha, Sorasak Lohchindarat, Chalermthai Aksilp, Naris Waranawat, Kaewta Intalapaporn, Ruamboon Arjwong, Nantaka Kongstan, Chariya Utenpitak, Ms. Hatairat Lerdsamran, Ms. Phisanu Pooruk, Supaloek Komolsiri, Kantima Sangsiriwut, Supeda Thongyen, Masfi'ah Rivai, Fitriany Darwis, Edha Barapadang, Winarni Arimanunggal, Inggraeni A Soeratman, Ns Emil, Dewi Lesthiowati, Budhi Antariksa, Marsaulina, Dewi Kartika Turbawati, Pudjiastuti Kartidjo, Rima Fajarwati, Nur Izzatun Nafsi, Juva Manurung, Neneng Kurniati, Isman Muhammad Toha, Evan Susandi, Eli Nurhayati, Nita Lestari, Ondri Dwi Sampurno, Hana Apsari Pawestri, Naning Agustiningsih, Christian Yoder, Joseph Chu, Celine Loke, Selina Chee, Rongfang Wang.

Investigators in the South East Asia Infectious Diseases Clinical Research Network

National Institute for Health Research and Development, Jakarta, Indonesia: Endang Rahayu Sedyaningsih, Moh Suhud Malik, Vivi Setiawaty, Trihono Trihono. Persahabatan Hospital Jakarta, Indonesia: Erlina Burhan, Tjandra Yoga Aditama, Prijanti Z. Soepandi, Lia G Partakusuma, Agung P Sutiyoso, Ika Priatni. Rumah Sakit Hasan Sadikan Bandung, Indonesia: Hadi Jusuf, Emmy Hermiyanti Pranggono, Arto Yuwono Soeroto, Djatnika Setiabudi, Dadang Hudaya Somasetia, Sri Sudarwati, Tini T Maskoen, Yovita Hartantri, Ida Parwati. Sulianto Saroso Hospital Jakarta, Indonesia: Sardikin Giriputro, Dewi Murniati, Sondang Maryutka Sirait, Tony Soetanto, Sri Sulastri, Rismali Agus, Adria Rusli, Sila Wiweka. Eijkman Oxford Clinical Research Unit Indonesia: Steve Wignall, Kevin Baird, Iko Safika. Bamrasnaradura Infectious Disease Institute Nonthaburi, Thailand: Chariya Sangsajja, Weerawat Manosuthi, Patama Sutha. Chest Disease Institute Nonthaburi, Thailand: Chareon Chuchottaworn, Piamlarp Sansayunh, Kittima Bangpattanasiri. Mahidol Oxford Research Unit Bangkok, Thailand: Walter R J Taylor, Kasia Stepniewska, Caroline Fukuda, Niklas Lindegardh, Nicholas White, Nick Day. Queen Sirikit National Institute of Child Health Bangkok, Thailand: Tawee Chotpitayasunondh, Piyarat Suntarattiwong, Umaporn Chantbuddhiwet, Supichaya Netsawang. Faculty of Medicine Siriraj Hospital, Mahidol University, Bangkok, Thailand: Kulkanya Chokephaibulkit, Nirun Vanprapar, Wasana Prasitsuebsai, Orasri Wittawatmongkol, Thanomsak Anekthananon, Winai Ratanasuwan, Yong Rongrungruang, Pilaipan Puthavathana. National University Hospital Singapore: Paul A Tambyah, Yee-Sin Leo, Dale Fisher, Louis Chai, Lawrence Lee, Raymond Lin. Children's Hospital 1 Ho Chi Minh City, Vietnam: Ngo Ngoc Quang Minh, Truong Huu Khanh, Le Phan Kim Thoa, Le Anh Tuan, Tran Thi My Dung, Lam Thi Thuy Ha, Le Minh Qui, Le Quoc Thinh, Nguyen Ngoc Tu Anh, Tran Anh Tuan, Trinh Hong Nhien, Bui Pham Phuong, Phan Tu Qui, Tieu Chau Thy, Bui Xuan Vu, Le Binh Bao Tinh, Dang Thi Thanh. Children's Hospital 2 Ho Chi Minh City, Vietnam: Vo Phuong Khanh, Do Chau Viet, Tran Thi Thuy, Vo Quoc Bao, Le Nguyen Nhat Trung, Ho Thi Kim Thoa, Tran Thi Ngoc Anh, Tran Thi Thu Loan, Tran Quynh Huong, Nguyen Thi Hanh Le, Ho Lu Viet, Ha Manh Tuan, Nguyen Thi Thanh Ha. Hospital for Tropical Diseases Ho Chi Minh City, Vietnam: Nguyen Van Vinh Chau, Nguyen Thanh Truong, Le Thi Thu Thao, Nguyen Thanh Phong, Pham Tran Dieu Hien, Pham Thi Hai Men, Cao Thi Tam, Tran Vinh Diet, Phan Tu Qui, Nguyen Van Hao. National Hospital for Tropical Diseases Hanoi, Vietnam: Nguyen Van Kinh, Nguyen Duc Hien, Nguyen Hong Ha, Hoang Van Tuyet, Nguyen Ngoc Phuc, Nguyen Quoc Thai, Luong Quoc Chinh, Nguyen Trung Cap, Vu Dinh Phu, Tran Thi Hai Ninh, Nguyen Vu Trung. National Hospital of Pediatrics Hanoi, Vietnam: Nguyen Thanh Liem, Bui Vu Huy, Luong Thi San, Phan Huu Phuc, Ho Anh Tuan, Cao Viet Tung, Doan Thi Mai Thanh, Le Xuan Ngoc, Pham Viet Hung, Dau Viet Hung, Pham Thu Hien. National Institute of Allergy and Infectious Diseases: John Beigel, Michael Polis, Elizabeth Higgs. 


\section{What is already known on this topic}

Clinical trials in patients with uncomplicated influenza have shown that treatment with oseltamivir has clinical and virological benefit when administered within 48 hours of onset of symptoms

Observational studies in severe influenza have shown that oseltamivir treatment, if given early, is associated with reduced mortality and shorter length of hospital stay. Reduced mortality has also been reported for patients with H5N1 influenza treated with oseltamivir Several authorities have suggested the use of double dose oseltamivir for severe influenza, although there is no clinical evidence to support this

\section{What this study adds}

In the largest randomised trial on the treatment of severe influenza, no clinical or virological benefit of double dose oseltamivir over standard dose was found

These findings have implications for both clinical management of severe influenza and for pandemic preparedness of emerging influenza viruses including the current H7N9 epidemic

Oxford University Clinical Research Unit Vietnam: Nghiem My Ngoc, Tran Thuy Ngan, Nguyen thi Tham, Duong Thi Tam, Nguyen Thi Thuy Chinh BKrong, Le Thi Tam Uyen, Vu thi Ty Hang, Tran Tan Thanh, Juliet E Bryant, Do Quang Ha, Vo Minh Hien, Lam An Nguyet, Le Nguyen Truc Nhu, Huynh Duy Khuong, Elaine Stockwell, Laura Merson, Jeremy J Farrar, Frederick Hayden, Tran Tinh Hien, Annette Fox, Menno D de Jong, Peter Horby, Heiman L Wertheim, H Rogier van Doorn.

Contributors: The investigators were involved in all aspects including protocol design, study execution and oversight, and the writing of the paper. All authors have seen and approved the final version. JF is guarantor.

Funding and sponsorship: The study was conducted by the South East Asia Infectious Diseases Clinical Research Network (www.seaicrn.org/ ) and supported by the National Institute of Allergy and Infectious Diseases and the Wellcome Trust of Great Britain. The Singapore site was supported by the Singapore National Medical Research Council. Competing interests: All authors have completed the ICMJE uniform disclosure form at www.icmje.org/coi_disclosure.pdf (available on request from the corresponding author) and declare: Paul Anantharajah Tambyah has received financial support from Inviragen, Fabentech, Sanofi-Pasteur, GSK, MSD, AstraZeneca, and 3M; M d De Jong has received financial support from AIMM therapeutics, Crucell BV, and AviBiopharma. F Hayden received grants from National Institute of Allergy and Infectious Disease/SAIC during the conduct of the study; personal fees from law firms, Practice Point Communications, and the American Society for Microbiology; since 2008 he has provided non-compensated advice to multiple companies involved in the development and/or marketing of antiviral agents or biologics for influenza including Roche, GSK, Biocryst, Medivector, Romark, Nexbio, Theraclone, and others.

Ethical approval: The protocol was approved by the ethics committees of all hospitals, the National Institute of Allergy and Infectious Diseases, and the Oxford University tropical ethics committee, and informed consent was given by all patients (or proxies).

Data sharing: Technical appendix, statistical code, and dataset available from the corresponding author. Consent from participants for data sharing was not obtained but the presented data are anonymised and risk of identification is low.

1 Harper SA, Bradley JS, Englund JA, File TM, Gravenstein S, Hayden FG, et al. Seasonal influenza in adults and-diagnosis, treatment, chemoprophylaxis, and institutional outbreak management: clinical practice guidelines of the Infectious Diseases Society of America. Clin Infect Dis 2009;48:1003-32.

2 Thompson WW, Shay DK, Weintraub E, Brammer L, Cox N, Andersen LJ, et al. Mortality associated with influenza and respiratory syncytial virus in the United States. JAMA 2003;289:179-86.

3 Dao CN, Kamimoto L, Nowell M, Reingold A, Gershman K, Meek J, et al. Adult hospitalizations for laboratory-positive influenza during the 2005-2006 through 2007-2008 seasons in the United States. J Infect Dis 2010;202:881-8.

4 Nicholson KG, Aoki FY, Osterhaus AD, Trottier S, Carewicz O, Mercier CH, et al. Efficacy and safety of oseltamivir in treatment of acute influenza: a randomised controlled trial. Neuraminidase Inhibitor Flu Treatment Investigator Group. Lancet 2000;355:1845-50.

5 Treanor JJ, Hayden FG, Vrooman PS, Barbarash R, Bettis R, Riff D, et al. Efficacy and safety of the oral neuraminidase inhibitor oseltamivir in treating acute influenza: a randomized controlled trial. US Oral Neuraminidase Study Group. JAMA 2000;283:1016-24.
6 Whitley RJ, Hayden FG, Reisinger KS, Young N, Dutkowski R, Ipe D, et al. Oral oseltamivir treatment of influenza in children. Pediatr Infect Dis $J$ 2001;20:127-33.

7 Hernan MA, Lipsitch M. Oseltamivir and risk of lower respiratory tract complications in patients with flu symptoms: a meta-analysis of eleven randomized clinical trials. Clin Infect Dis 2011;53:277-9.

8 McGeer A, Green KA, Plevneshi A, Siddiqi N, Raboud J, Low DE, et al. Antiviral therapy and outcomes of influenza requiring hospitalization in Ontario, Canada. Clin Infect Dis 2007;45:1568-75.

9 Fanella ST, Pinto MA, Bridger NA, Bullard JM, Coombs JM, Crockett ME, et al. Pandemic (H1N1) 2009 influenza in hospitalized children in Manitoba: nosocomial transmission and lessons learned from the first wave. Infect Control Hosp Epidemiol 2011;32:435-43.

10 Adisasmito W, Chan PK, Lee N, Oner AF, Gasimov V, Aghayev F, et al. Effectiveness of antiviral treatment in human influenza A(H5N1) infections: analysis of a Global Patient Registry. J Infect Dis 2010;202:1154-60.

11 Hsu J, Santesso N, Mustafa R, Brozek J, Chen YL, Hopkins JP, et al. Antivirals for treatment of influenza: a systematic review and meta-analysis of observational studies. Ann Intern Med 2012;156:512-24.

12 Yang SG, Cao B, Liang LR, Li XL, Xiao YH, Cao ZX, et al. Antiviral therapy and outcomes of patients with pneumonia caused by influenza A pandemic (H1N1) virus. PLOS ONE 2012; 7:e29652.

13 Hayden FG, Jennings L, Robson R, Schiff G, Jackson H, Rana B, et al. Oral oseltamivir in human experimental influenza B infection. Antivir Ther 2000;5:205-13.

14 Hayden FG, Treanor JJ, Fritz RS, Lobo M, Betts RF, Miller M, et al. Use of the oral neuraminidase inhibitor oseltamivir in experimental human influenza: randomized controlled trials for prevention and treatment. JAMA 1999;282:1240-6.

15 Abdel-Ghafar AN, Chotpitayasunondh T, Gao Z, Hayden FG, Nguen DH, de Jong MD, et al. Update on avian influenza A (H5N1) virus infection in humans. N Engl J Med 2008:358:261-73.

16 Bautista E, Chotpitayasunondh T, Gao Z, Harper SA, Shaw M, Uyeki TM, et al. Clinical aspects of pandemic 2009 influenza A (H1N1) virus infection. N Engl J Med 2010;362:1708-19

17 Beigel JH, Farrar J, Han AM, Hayden FG, de Jong MD, Lochindarat S, et al. Avian influenza A (H5N1) infection in humans. N Engl J Med 2005;353:1374-85.

18 Gao R, Cao B, Hu Y, Feng Z, Wang D, Hu W, et al. Human infection with a novel avian-origin influenza A (H7N9) virus. N Engl J Med 2013 Apr 11 (epub ahead of print).

19 Cockcroft DW, Gault MH. Prediction of creatinine clearance from serum creatinine. Nephron 1976;16:31-41.

20 Schwartz GJ, Haycock GB, Edelmann CM Jr, Spitzer A. A simple estimate of glomerular filtration rate in children derived from body length and plasma creatinine. Pediatrics 1976;58:259-63.

21 FDA clears new CDC test to detect human influenza. US Department of Health and Human Services, 2008. www.hhs.gov/news/press/2008pres/09/20080930a.html.

$22 \mathrm{CDC}$ protocol of realtime RTPCR for influenza A(H1N1). World Health Organization, 2009. www.who.int/csr/resources/publications/swineflu/realtimeptpcr/en/index.html.

23 De Jong MD, Bach VC, Phan TQ, Vo MH, Tran TT, Nguyen BH, et al. Fatal avian influenza A (H5N1) in a child presenting with diarrhea followed by coma. N Engl J Med 2005;352:686-91.

24 WHO Manual on Animal Influenza Diagnosis and Surveillance. World Health Organization, 2005.

25 De Jong MD, Tran TT, Truong HK, Vo MH, Smith GJ, Nguyen VC, et al. Oseltamivir resistance during treatment of influenza A (H5N1) infection. N Engl J Med 2005;353:2667-72.

26 Ison MG, de Jong MD, Gilligan KJ, Higgs ES, Pavia AT, Pierson J, et al. End points for testing influenza antiviral treatments for patients at high risk of severe and life-threatening disease. $J$ Infect Dis 2010;201:1654-62.

27 Ison MG, Gnann JW Jr, Nagy-Agren S, Treannor J, Paya C, Steigbigel R, et al. Safety and efficacy of nebulized zanamivir in hospitalized patients with serious influenza. Antivir Ther 2003;8:183-90.

28 Sato M, Hosoya M, Kato K, Suzuki H. Viral shedding in children with influenza virus infections treated with neuraminidase inhibitors. Pediatr Infect Dis J 2005:24:931-2.

29 Schag CC, Heinrich RL, Ganz PA. Karnofsky performance status revisited: reliability, validity, and guidelines. J Clin Oncol 1984;2:187-93.

30 Dutkowski R, Smith JR, Davies BE. Safety and pharmacokinetics of oseltamivir at standard and high dosages. Int $J$ Antimicrob Agents 2010;35:461-7.

31 Lackenby A, Hungnes O, Dudman SG, Meijer A, Paget WJ, Hay AJ, et al. Emergence of resistance to oseltamivir among influenza $\mathrm{A}(\mathrm{H} 1 \mathrm{~N} 1)$ viruses in Europe. Euro Surveill 2008;13:8026.

32 Aoki FY, Macleod MD, Paggiaro P, Carewicz O, El Sawy A, Wat C, et al. Early administration of oral oseltamivir increases the benefits of influenza treatment. $J$ Antimicrob Chemother 2003;51:123-9.

$33 \mathrm{Li} \mathrm{IW}$, Hung IF, To KK, Chan KH, Wong SS, Chan JF, et al. The natural viral load profile of patients with pandemic 2009 influenza $\mathrm{A}(\mathrm{H} 1 \mathrm{~N} 1)$ and the effect of oseltamivir treatment. Chest 2010;137:759-68. 
34 Ling LM, Chow AL, Lye DC, Tan AS, Krishnan P, Ciu L, et al. Effects of early oseltamivir therapy on viral shedding in 2009 pandemic influenza A (H1N1) virus infection. Clin Infect Dis 2010;50:963-9.

35 Valli MB, Selleri M, Meschi S, Zaccaro P, Vincenti D, Lalle E, et al. Hemagglutinin 222 variants in pandemic (H1N1) 2009 virus. Emerg Infect Dis 2011;17:749-51.

36 Yu H, Liao Q, Yuan Y, Zhou L, Xiang N, Huai Y, et al. Effectiveness of oseltamivir on disease progression and viral RNA shedding in patients with mild pandemic 2009 influenza A H1N1: opportunistic retrospective study of medical charts in China. BMJ 2010;341:c4779.

37 Lee N, Chan PK, Choi KW, Lui G, Wong B, Cockram CS, et al. Factors associated with early hospital discharge of adult influenza patients. Antivir Ther 2007;12:501-8.

38 Li IW, Hung IF, To KK, Chan KH, Wong SS, Chan JF, et al. The natural viral load profile of patients with pandemic 2009 influenza $\mathrm{A}(\mathrm{H} 1 \mathrm{~N} 1)$ and the effect of oseltamivir treatment. Chest 2010;137:759-68.

39 To KK, Hung IF, Li IW, Lee KL, Koo CK, Yan WW, et al. Delayed clearance of viral load and marked cytokine activation in severe cases of pandemic H1N1 2009 influenza virus infection. Clin Infect Dis 2010;50:850-9.

40 Kumar A. Early versus late oseltamivir treatment in severely ill patients with 2009 pandemic influenza A (H1N1): speed is life. J Antimicrob Chemother 2011;66:959-63.

41 Lee N, Chan PK, Hui DS, Rainer TH, Wong E Choi KW, et al Viral loads and duration of viral shedding in adult patients hospitalized with influenza. J Infect Dis 2009;200:492-500.
$42 \mathrm{He} \mathrm{G}$, Massarella J, Ward P. Clinical pharmacokinetics of the prodrug oseltamivir and its active metabolite Ro 64-0802. Clin Pharmacokinet 1999;37:471-84.

43 Schentag JJ, Hill G, Chu T, Rayner CR. Similarity in pharmacokinetics of oseltamivir and oseltamivir carboxylate in Japanese and Caucasian subjects. J Clin Pharmacol 2007;47:689-96.

44 Ison MG, Hui DS, Clezy K, O'Neil BJ, Flynt A, Collis PJ, et al. A clinical trial of intravenous peramivir compared with oral oseltamivir for the treatment of seasonal influenza in hospitalized adults. Antivir Ther 2012 Oct 30;doi:10.3851/IMP2442.

\section{Accepted: 07 May 2013}

\section{Cite this as: BMJ 2013;346:f3039}

This is an Open Access article distributed in accordance with the Creative Commons Attribution Non Commercial (CC BY-NC 3.0) license, which permits others to distribute, remix, adapt, build upon this work non-commercially, and license their derivative works on different terms, provided the original work is properly cited and the use is non-commercial. See: http://creativecommons.org/licenses/by-nc/3.0/. 


\section{Tables}

Table 1/ Patients' characteristics at enrolment in study of double or standard dose oseltamivir for treatment of severe influenza. Continuous data are shown as mean (SD), categorical data as number (percentage)

\begin{tabular}{|c|c|c|c|c|c|}
\hline \multirow[b]{2}{*}{ Parameter } & \multirow[b]{2}{*}{ Total } & \multicolumn{2}{|c|}{ Children $(n=246)$} & \multicolumn{2}{|c|}{ Adults $(n=80)$} \\
\hline & & Double dose $(n=124)$ & Standard dose $(n=122)$ & Double dose $(n=41)$ & Standard dose $(n=39)$ \\
\hline Sex (male) & 185 & $79(63.7)$ & $71(58.2)$ & $17(41.5)$ & $18(46.2)$ \\
\hline Age (years) & - & $2.8(2.4)$ & $2.8(1.9)$ & $37.9(13.6)$ & $45.9(18.7)$ \\
\hline Duration of illness (days) & - & $5.3(2.1)$ & $5.1(2)$ & $5.6(2.2)$ & $4.9(2.5)$ \\
\hline Karnofsky score $<50$ & 43 & $5(4)$ & $11(9)$ & $13(31.7)$ & $14(36.8)$ \\
\hline \multicolumn{6}{|l|}{ Symptoms: } \\
\hline Cough & 319 & $123(99)$ & $120(99)$ & 37 (95) & $39(100)$ \\
\hline Dyspnoea & 139 & $55(44)$ & $49(40)$ & $16(39)$ & $19(49)$ \\
\hline Vomiting & 107 & $42(34.1)$ & $45(36.9)$ & $11(28.9)$ & $9(23.7)$ \\
\hline Diarrhoea & 75 & $24(19.5)$ & & $10(25)$ & $9(23.7)$ \\
\hline \multicolumn{6}{|l|}{ Underlying comorbidity: } \\
\hline Asthma & 24 & $8(6.5)$ & $11(9)$ & $2(4.9)$ & $3(7.7)$ \\
\hline Malnourished & 8 & $3(2.4)$ & $3(2.5)$ & 0 & $2(5.1)$ \\
\hline Congenital heart disease & 7 & $2(1.6)$ & $4(3.3)$ & $1(2.4)$ & 0 \\
\hline Hypertension & 12 & 0 & 0 & $3(7.3)$ & $9(23.1)$ \\
\hline Diabetes mellitus & 1 & 0 & 0 & $1(2.4)$ & 0 \\
\hline Alcoholism & 4 & 0 & 0 & $2(4.9)$ & $2(5.1)$ \\
\hline HIV/AIDS & 2 & $1(0.8)$ & 0 & $1(2.4)$ & 0 \\
\hline Antivirals before enrolment & 76 & $12(9.7)$ & $12(9.8)$ & $26(63.4)$ & $26(66.7)$ \\
\hline BMI & - & $15.9(2.2)$ & $16(2.2)$ & $22(4.5)$ & $22.8(4.1)$ \\
\hline \multicolumn{6}{|l|}{ Signs: } \\
\hline Tachypnoea & 183 & $73(59)$ & $66(54)$ & $20(49)$ & $24(62)$ \\
\hline Febrile $\left(>38^{\circ} \mathrm{C}\right)$ & 175 & $70(56)$ & $67(55)$ & $18(44)$ & $20(51)$ \\
\hline Respiratory rate & - & $43(11)$ & $43(10$ & $24(7)$ & $26(7)$ \\
\hline \multicolumn{6}{|l|}{ Laboratory data: } \\
\hline White cell count $\times 103 / \mu \mathrm{L}$ & - & $9.041(4.3)$ & $8.247(4.2)$ & $7.895(5.9)$ & $8.086(5.4)$ \\
\hline Lymphocytes \% & - & $49(20)$ & $51(19)$ & $24(16)$ & $19(13)$ \\
\hline Creatinine $\mu \mathrm{mol} / \mathrm{L}$ & - & $41.5(29.3)$ & $38.0(14.8)$ & $104.1(88.9)$ & $102.2(72.9)$ \\
\hline Glucose mmol/L & - & $5.6(2.5)$ & $5.3(1.2)$ & $7.8(4)$ & $9.1(6.8)$ \\
\hline LDH IU/L & - & $694(331)$ & $690(273)$ & 845 (1272) & $971(1250)$ \\
\hline \multicolumn{6}{|l|}{ Virological data: } \\
\hline $1977 \mathrm{H} 1 \mathrm{~N} 1$ & 38 & $13(10)$ & $21(17)$ & $1(2)$ & $3(8)$ \\
\hline H1N1-pdm09 & 72 & $19(15)$ & $22(18)$ & $17(41)$ & $14(36)$ \\
\hline H3N2 & 133 & $63(51)$ & $50(41)$ & $9(22)$ & $11(28)$ \\
\hline $\mathrm{H} 5 \mathrm{~N} 1$ & 17 & $2(2)$ & $2(2)$ & $7(17)$ & $6(15)$ \\
\hline $\mathrm{B}$ & 53 & $23(19)$ & $23(19)$ & $5(12)$ & $2(5)$ \\
\hline Not detected & 13 & $4(3)$ & $4(3)$ & $2(5)$ & $3(8)$ \\
\hline \multicolumn{6}{|l|}{ Radiology: } \\
\hline Infiltrates on CXR & 266 & $96(77)$ & $96(79)$ & $39(95)$ & $35(90)$ \\
\hline ARDS & 25 & $3(2.4)$ & $4(3.3)$ & $8(19.5)$ & $10(25.6)$ \\
\hline \multicolumn{6}{|l|}{ Treatment needed: } \\
\hline Intensive care & 57 & $6(4.8)$ & $8(6.6)$ & $19(46.3)$ & $24(61.5)$ \\
\hline Supplemental oxygen & 93 & $23(18.5)$ & $17(13.9)$ & $25(61)$ & $28(71.8)$ \\
\hline Mechanical ventilation & 34 & $3(2.4)$ & $5(4.1)$ & $11(26.8)$ & $15(38.5)$ \\
\hline
\end{tabular}


Table 1 (continued)

\begin{tabular}{lccc} 
& Children $(n=246)$ & Adults $(n=80)$ & Total \\
\cline { 3 - 3 } Parameter & Double dose $(n=124)$ Standard dose $(n=122)$ & & Double dose $(n=41)$ Standard dose $(n=39)$ \\
LDH=lactate dyhydrogenase; LDH CXR=chest $x$ ray; ARDS=acute respiratory distress syndrome. & \\
\hline
\end{tabular}


Table 2/ Subgroup analyses of percentages of patients still positive for viral RNA at day five of treatment in samples taken from nose. Patients grouped according to age, detected virus, and day of illness on enrolment

\begin{tabular}{|c|c|c|c|c|c|c|c|}
\hline & \multicolumn{3}{|c|}{ Standard dose } & \multicolumn{3}{|c|}{ Double dose } & \multirow[b]{2}{*}{$\mathbf{P}$ value $\ddagger$} \\
\hline & $\mathrm{No}^{*}(\%)$ & Copy number (range)† & $\begin{array}{c}\text { No with } \\
\text { positive } \\
\text { quantitative } \\
\text { RT-PCR result }\end{array}$ & No* $(\%)$ & Copy number (range) $\dagger$ & $\begin{array}{c}\text { No with } \\
\text { positive } \\
\text { quantitative } \\
\text { RT-PCR result }\end{array}$ & \\
\hline \multicolumn{8}{|l|}{ Age groups } \\
\hline All & 22/143 (15.4) & $\begin{array}{c}4.33 e+03 \\
(1.00 e+03-7.40 e+04)\end{array}$ & 8 & $22 / 150(14.7)$ & $\begin{array}{c}2.94 \mathrm{e}+03 \\
(1.00 \mathrm{e}+03-5.62 \mathrm{e}+04)\end{array}$ & 9 & 0.85 \\
\hline$<18$ & 20/116 (17.2) & $\begin{array}{c}4.97 e+03 \\
(1.00 e+03-7.40 e+04)\end{array}$ & 7 & $19 / 120(15.8)$ & $\begin{array}{c}2.88 e+03 \\
(1.00 e+03-4.62 e+04)\end{array}$ & & 0.77 \\
\hline $0-4$ & $17 / 105(16.2)$ & $\begin{array}{c}1.45 e+04 \\
(2.55 e+03-7.40 e+04)\end{array}$ & 6 & 18/106 (17) & $\begin{array}{c}2.88 e+03 \\
(1.00 e+03-4.62 e+04)\end{array}$ & 8 & 0.88 \\
\hline $5-17$ & 3/11 (27.3) & $\begin{array}{c}1.00 \mathrm{e}+03 \\
(1.00 \mathrm{e}+03-1.00 \mathrm{e}+03)\end{array}$ & 1 & $1 / 14(7.1)$ & - & 0 & 0.17 \\
\hline$\geq 18$ & 2/27 (7.4) & $\begin{array}{c}1.35 e+03 \\
(1.35 e+03-1.35 e+03)\end{array}$ & 1 & $3 / 30(10)$ & $\begin{array}{c}5.62 e+04 \\
(5.62 e+04-5.62 e+04) \\
\end{array}$ & 1 & 0.76 \\
\hline $18-59$ & $0 / 17(0)$ & - & 0 & $3 / 28(10.7)$ & $\begin{array}{c}5.62 e+04 \\
(5.62 e+04-5.62 e+04)\end{array}$ & 1 & 0.17 \\
\hline$\geq 60$ & $2 / 10(20)$ & $\begin{array}{c}1.35 e+03 \\
(1.35 e+03-1.35 e+03)\end{array}$ & 1 & $0 / 2(0)$ & - & 0 & 0.49 \\
\hline \multicolumn{8}{|l|}{ Virus type } \\
\hline $1977 \mathrm{H} 1 \mathrm{~N} 1$ & $2 / 23(8.7)$ & $\begin{array}{c}4.97 e+03 \\
(4.97 e+03-4.97 e+03)\end{array}$ & 1 & $3 / 13(23.1)$ & - & 0 & 0.23 \\
\hline H3N2 & $13 / 61(21.3)$ & $\begin{array}{c}3.68 e+03 \\
(1.35 e+03-2.64 e+04)\end{array}$ & 5 & $12 / 70(17.1)$ & $\begin{array}{c}8.93 e+03 \\
(1.04 e+03-4.62 e+04)\end{array}$ & 5 & 0.54 \\
\hline H1N1-pdm09 & 2/34 (5.9) & - & 0 & $2 / 36(5.6)$ & $\begin{array}{c}2.94 e+03 \\
(2.94 e+03-2.94 e+03)\end{array}$ & 1 & 0.95 \\
\hline $\mathrm{H} 5 \mathrm{~N} 1$ & $0 / 0(0)$ & - & 0 & $1 / 4(25)$ & $\begin{array}{c}5.62 e+04 \\
(5.62 e+04-5.62 e+04)\end{array}$ & 1 & \\
\hline B & $5 / 25(20)$ & $\begin{array}{c}3.75 \mathrm{e}+04 \\
(1.00 \mathrm{e}+03-7.40 \mathrm{e}+04)\end{array}$ & 2 & $4 / 27(14.8)$ & $\begin{array}{c}1.00 e+03 \\
(1.00 e+03-1.00 e+03)\end{array}$ & 2 & 0.62 \\
\hline \multicolumn{8}{|c|}{ Time to treatment (days from onset of illness) } \\
\hline Within 2 & $4 / 17(23.5)$ & $\begin{array}{c}1.33 e+04 \\
(2.55 e+03-2.40 e+04)\end{array}$ & 2 & $6 / 14(42.9)$ & $\begin{array}{c}2.94 \mathrm{e}+03 \\
(2.82 \mathrm{e}+03-4.62 \mathrm{e}+04)\end{array}$ & 3 & 0.25 \\
\hline Within 3 & 6/38 (15.8) & $\begin{array}{c}1.33 e+04 \\
(2.55 e+03-2.40 e+04)\end{array}$ & 2 & 10/33 (30.3) & $\begin{array}{c}2.94 e+03 \\
(1.04 e+03-4.62 e+04)\end{array}$ & 5 & 0.14 \\
\hline Within 4 & $12 / 64(18.8)$ & $\begin{array}{c}1.33 e+04 \\
(1.35 e+03-7.40 e+04)\end{array}$ & 4 & $14 / 59(23.7)$ & $\begin{array}{c}5.94 e+03 \\
(1.04 e+03-4.62 e+04)\end{array}$ & 6 & 0.50 \\
\hline$>4$ & $10 / 79$ (12.7) & $\begin{array}{c}4.33 e+03 \\
(1.00 e+03-2.64 e+04)\end{array}$ & 4 & 7/91 (7.7) & $\begin{array}{c}2.86 e+04 \\
(1.00 e+03-5.62 e+04)\end{array}$ & 2 & \\
\hline
\end{tabular}

RT-PCR=reverse transcriptase polymerase chain reaction.

*Patients still positive by qualitative RT-PCR in each arm per subgroup.

†Calculated from results of quantitative RT-PCR.

‡From $x^{2}$ for comparison of number of patients still positive by qualitative RT-PCR in each arm. 
Table 3 | Subgroup analyses of percentages of patients still positive for viral RNA at day 5 of treatment in samples taken from throat. Patients were grouped according to age, detected virus, and day of illness on enrolment

\begin{tabular}{|c|c|c|c|c|c|c|c|}
\hline & \multicolumn{3}{|c|}{ Standard dose } & \multicolumn{3}{|c|}{ Double dose } & \multirow[b]{2}{*}{ P value } \\
\hline & No* $(\%)$ & Copy number (range)† & $\begin{array}{c}\text { No with } \\
\text { positive } \\
\text { quantitative } \\
\text { RT-PCR result }\end{array}$ & No* $(\%)$ & Copy number (range)† & $\begin{array}{c}\text { No with } \\
\text { positive } \\
\text { quantitative } \\
\text { RT-PCR result }\end{array}$ & \\
\hline \multicolumn{8}{|l|}{ Age groups } \\
\hline All & $33 / 143(23.1)$ & $\begin{array}{c}3.85 e+03 \\
(1.00 e+03-3.01 e+05)\end{array}$ & 11 & 29/151 (19.2) & $1.83 e+04(1.00 e+03-4.07 e+05)$ & 14 & 0.40 \\
\hline$<18$ & $29 / 116(25)$ & $\begin{array}{c}4.12 \mathrm{e}+03 \\
(1.00 \mathrm{e}+03-3.01 \mathrm{e}+05)\end{array}$ & 10 & 23/119 (19.3) & $1.86 e+04(1.16 e+03-1.45 e+05)$ & 11 & 0.30 \\
\hline $0-4$ & 25/105 (23.8) & $\begin{array}{c}4.12 e+03 \\
(1.00 e+03-3.01 e+05)\end{array}$ & 10 & $22 / 106(20.8)$ & $1.95 e+04(2.06 e+03-1.45 e+05)$ & 10 & 0.60 \\
\hline 5-17 & $4 / 11(36.4)$ & - & 0 & $1 / 13(7.7)$ & $1.16 e+03(1.16 e+03-1.16 e+03)$ & 1 & 0.08 \\
\hline$\geq 18$ & $4 / 27(14.8)$ & $\begin{array}{c}1.00 \mathrm{e}+03 \\
(1.00 \mathrm{e}+03-1.00 \mathrm{e}+03)\end{array}$ & 1 & $6 / 32(18.8)$ & $1.00 e+03(1.00 e+03-4.07 e+05)$ & 3 & 0.73 \\
\hline $18-59$ & 2/17 (11.8) & $\begin{array}{c}1.00 e+03 \\
(1.00 e+03-1.00 e+03)\end{array}$ & 1 & $5 / 27(16.7)$ & $2.04 e+05(1.00 e+03-4.07 e+05)$ & 1 & 0.68 \\
\hline$\geq 60$ & $2 / 10(20)$ & - & 0 & $1 / 2(50)$ & $1.00 \mathrm{e}+03(1.00 \mathrm{e}+03-1.00 \mathrm{e}+03)$ & 1 & 0.37 \\
\hline \multicolumn{8}{|l|}{ Virus type } \\
\hline $1977 \mathrm{H} 1 \mathrm{~N} 1$ & 4/23 (17.4) & $\begin{array}{c}4.39 e+03 \\
(4.39 e+03-4.39 e+03)\end{array}$ & 1 & $3 / 12(25)$ & $1.79 e+04(1.21 e+04-1.13 e+05)$ & 3 & 0.59 \\
\hline H3N2 & $17 / 60(28.3)$ & $\begin{array}{c}3.85 e+03 \\
(2.08 e+03-3.01 e+05)\end{array}$ & 5 & $15 / 71(21.1)$ & $1.05 e+04(1.16 e+03-1.45 e+05)$ & 6 & 0.34 \\
\hline H1N1-pdm09 & $4 / 34(11.8)$ & $\begin{array}{c}1.00 \mathrm{e}+03 \\
(1.00 \mathrm{e}+03-1.00 \mathrm{e}+03)\end{array}$ & 1 & $3 / 37(8.1)$ & - & 0 & 0.61 \\
\hline $\mathrm{H} 5 \mathrm{~N} 1$ & $0 / 0(0)$ & - & 0 & $2 / 4(50)$ & $2.04 e+05(1.00 e+03-4.07 e+05)$ & 2 & \\
\hline B & $8 / 26(30.8)$ & $\begin{array}{c}4.58 e+03 \\
(1.00 e+03-2.86 e+04)\end{array}$ & 4 & $6 / 27(22.2)$ & $2.03 e+04(1.00 e+03-3.44 e+04)$ & 3 & 0.48 \\
\hline \multicolumn{8}{|c|}{ Time to treatment (days from onset of illness) } \\
\hline Within 2 & $5 / 17(29.4)$ & $\begin{array}{c}3.57 e+03 \\
(2.74 e+03-4.39 e+03)\end{array}$ & 2 & $7 / 14(50)$ & $2.39 e+03(1.00 e+03-1.45 e+05)$ & 5 & 0.24 \\
\hline Within 3 & $7 / 37(18.9)$ & $\begin{array}{c}3.57 e+03 \\
(2.74 e+03--4.39 e+03) \\
\end{array}$ & 2 & $10 / 33(30.3)$ & $1.01 e+04(1.00 e+03-1.45 e+05)$ & 8 & 0.27 \\
\hline Within 4 & 14/63 (22.2) & $\begin{array}{c}2.41 \mathrm{e}+03 \\
(1.00 \mathrm{e}+03-8.16 \mathrm{e}+03)\end{array}$ & 6 & $15 / 61(24.6)$ & $1.83 e+04(1.00 e+03-1.45 e+05)$ & 10 & 0.76 \\
\hline$>4$ & $19 / 80(23.8)$ & $\begin{array}{c}1.59 \mathrm{e}+04 \\
(1.00 \mathrm{e}+03-3.01 \mathrm{e}+05)\end{array}$ & 5 & $12 / 86(14)$ & $1.21 e+04(1.00 e+03-4.07 e+05)$ & 3 & \\
\hline
\end{tabular}

RT-PCR=reverse transcriptase polymerase chain reaction.

*Patients still positive by qualitative RT-PCR in each arm per subgroup.

†Calculated from results of quantitative RT-PCR.

¥From $x^{2}$ for comparison of number of patients still positive by qualitative RT-PCR in each arm. 
Table 4| Risk factors identified by conditional multiple logistic regression for being viral RNA negative by RT-PCR on day five. Important non-significant factors are also included. Patients with no detected influenza were excluded from analysis

\begin{tabular}{|c|c|c|c|c|}
\hline Factor & No of patients* & No of events* & OR $(95 \% \mathrm{Cl})$ & $P$ value \\
\hline Nose viral load $\dagger$ & 304 & 213 & 0.73 (0.62 to 0.86$)$ & $<0.01$ \\
\hline Karnofsky score $<50 \ddagger$ & 35 & 15 & $0.24(0.08$ to 0.78$)$ & 0.02 \\
\hline Child & 236 & 49 & $0.62(0.17$ to 2.22$)$ & 0.46 \\
\hline Double dose oseltamivir & 156 & 112 & $1.27(0.73$ to 2.20$)$ & 0.39 \\
\hline \multicolumn{5}{|l|}{ Virus type: } \\
\hline $\mathrm{B}$ & 51 & 36 & $0.88(0.32$ to 2.41$)$ & 0.80 \\
\hline H3N2 & 132 & 91 & $0.72(0.30$ to 1.70$)$ & 0.45 \\
\hline $\mathrm{H} 5 \mathrm{~N} 1$ & 15 & 2 & $0.03(0.00$ to 0.64$)$ & 0.03 \\
\hline H12009 & 68 & 57 & 1.01 (0.34 to 2.97) & 0.99 \\
\hline H1N1-pdm & 38 & 27 & Reference & - \\
\hline
\end{tabular}

RT-PCR=reverse transcriptase polymerase chain reaction.

*Total number of patients in group and total number negative for viral RNA by RT-PCR on day $5 ; 304$ patients with 213 events were included in analysis. †After $\log _{10}(x+1)$ transformation, odds ratio corresponds to change in odds associated with 10 -fold increase in viral load.

$\ddagger$ Patients with score $<50$ require frequent medical attention. 
Table 5| Patients' characteristics and causes of death of 21 patients who died in trial of double or standard dose oseltamivir for treatment of severe influenza

\begin{tabular}{|c|c|c|c|c|c|c|}
\hline Country & Virus & Sex & Age & Day of illness on admission & Day since admission at death & Cause of death \\
\hline \multicolumn{7}{|c|}{ Double dose arm } \\
\hline Indonesia & ND & $\mathrm{F}$ & 18 & 9 & 2 & Respiratory failure \\
\hline Vietnam & $\mathrm{B}$ & M & 43 & 6 & 7 & Respiratory failure \\
\hline Vietnam & H3N2 & M & 2 & 5 & 13 & Respiratory failure \\
\hline Vietnam & H3N2 & $\mathrm{M}$ & 54 & 7 & 1 & MOF \\
\hline Vietnam & $\mathrm{H} 5 \mathrm{~N} 1$ & $\mathrm{~F}$ & 28 & 7 & 12 & Severe hypoxaemia \\
\hline Vietnam & H5N1 & M & 39 & 6 & 3 & Respiratory failure \\
\hline Vietnam & $\mathrm{H} 5 \mathrm{~N} 1$ & M & 10 & 8 & 3 & Respiratory failure \\
\hline Indonesia & $\mathrm{H} 5 \mathrm{~N} 1$ & $\mathrm{~F}$ & 28 & 8 & 1 & ARDS and respiratory failure \\
\hline Indonesia & H5N1 & $\mathrm{F}$ & 16 & 10 & 5 & ARDS \\
\hline Indonesia & $\mathrm{H} 5 \mathrm{~N} 1$ & $\mathrm{M}$ & 30 & 7 & 4 & MOF \\
\hline Indonesia & $\mathrm{H} 5 \mathrm{~N} 1$ & $\mathrm{~F}$ & 31 & 8 & 5 & MOF \\
\hline Vietnam & $\mathrm{H} 5 \mathrm{~N} 1$ & $\mathrm{M}$ & 3 & 5 & 2 & ARDS and shock \\
\hline \multicolumn{7}{|c|}{ Standard dose arm } \\
\hline Vietnam & ND & $\mathrm{M}$ & 44 & 6 & 1 & MOF \\
\hline Vietnam & H1N1pdm09 & $\mathrm{F}$ & 22 & 6 & 4 & MOF \\
\hline Vietnam & $\mathrm{H} 5 \mathrm{~N} 1$ & $\mathrm{M}$ & 31 & 5 & 1 & Respiratory failure \\
\hline Indonesia & $\mathrm{H} 5 \mathrm{~N} 1$ & M & 8 & 3 & 1 & Respiratory failure \\
\hline Indonesia & $\mathrm{H} 5 \mathrm{~N} 1$ & $\mathrm{M}$ & 9 & 10 & 1 & Respiratory failure \\
\hline Indonesia & $\mathrm{H} 5 \mathrm{~N} 1$ & $\mathrm{~F}$ & 30 & 6 & 2 & ARDS and respiratory failure \\
\hline Indonesia & $\mathrm{H} 5 \mathrm{~N} 1$ & $\mathrm{M}$ & 47 & 7 & 2 & Septic shock \\
\hline Indonesia & $\mathrm{H} 5 \mathrm{~N} 1$ & $\mathrm{M}$ & 32 & 10 & 2 & MOF \\
\hline Indonesia & $\mathrm{H} 5 \mathrm{~N} 1$ & $\mathrm{~F}$ & 29 & 10 & 1 & Respiratory failure \\
\hline
\end{tabular}


Table 6 | Effect of dose on measures of respiratory compromise, expressed as Kaplan Meier estimates and $95 \%$ confidence intervals, in study of double or standard dose oseltamivir for treatment of severe influenza

\begin{tabular}{|c|c|c|c|}
\hline & Double dose & Standard dose & P value* \\
\hline \multicolumn{4}{|l|}{ Receipt of oxygen } \\
\hline Median (IQR) time (days) & $3(2-5)$ & $3.5(2-7)$ & $0.48 \dagger$ \\
\hline No of patients & 50 & 48 & - \\
\hline$\%$ on oxygen on day 3 & 55.5 (39.7 to 68.7 ) & 60.5 (44.1 to 73.4$)$ & \multirow[t]{4}{*}{$0.72 \ddagger$} \\
\hline$\%$ on oxygen on day 5 & 36.3 (21.7 to 51.1$)$ & 42.8 (26.8 to 57.8$)$ & \\
\hline$\%$ on oxygen on day 7 & 22.7 (9.6 to 39.1$)$ & 28.5 (14.4 to 44.4$)$ & \\
\hline$\%$ on oxygen on day 10 & $17.0(5.4$ to 34.1$)$ & 28.5 (14.4 to 44.4$)$ & \\
\hline \multicolumn{4}{|c|}{ Time in intensive care unit (ICU) } \\
\hline Median (IQR) time (days) & $4.5(3-6)$ & $5(2-11)$ & $0.66 \dagger$ \\
\hline No of patients & 27 & 34 & - \\
\hline$\%$ in ICU on day 3 & $84.7(64.0$ to 94.0$)$ & 77.1 (57.8 to 88.5$)$ & \multirow[t]{4}{*}{$0.57 \ddagger$} \\
\hline$\%$ in ICU on day 5 & $47.4(23.0$ to 68.4$)$ & $60.9(40.1$ to 76.4$)$ & \\
\hline$\%$ in ICU on day 7 & $37.9(14.5$ to 61.5$)$ & $38.8(18.7$ to 58.5$)$ & \\
\hline$\%$ in ICU on day 10 & 25.3 (5.3 to 52.5$)$ & $33.2(14.5$ to 53.3$)$ & \\
\hline \multicolumn{4}{|l|}{ Time on ventilation } \\
\hline Median (IQR) time (days) & $2.5(1-16)$ & $8(1-16)$ & $0.58 \dagger$ \\
\hline No of patients & 19 & 21 & - \\
\hline$\%$ on ventilation on day 3 & 89.5 (64.1 to 97.3$)$ & 85.7 (62.0 to 95.2$)$ & \multirow[t]{4}{*}{$0.68 \ddagger$} \\
\hline$\%$ on ventilation on day 5 & $71.6(26.1$ to 92.0$)$ & 75.0 (42.4 to 90.8$)$ & \\
\hline$\%$ on ventilation on day 7 & $71.6(26.1$ to 92.0$)$ & 75.0 (42.4 to 90.8$)$ & \\
\hline$\%$ on ventilation on day 10 & $71.6(26.1$ to 92.0$)$ & $45.0(11.9$ to 74.1$)$ & \\
\hline \multicolumn{4}{|c|}{$\begin{array}{l}\text { *For comparison between arms. } \\
\text { †Kruskal-Wallis test. } \\
\text { †Log rank test. }\end{array}$} \\
\hline
\end{tabular}


Table $7 \mid$ Adverse events experienced by patients in study of double or standard dose oseltamivir for treatment of severe influenza

\begin{tabular}{lccc} 
Parameter & All & Double dose & Standard dose \\
No (\%) of patients with adverse event & $55 / 326(16.8)$ & $28 / 165(16.9)$ & $27 / 161(16.8)^{*}$ \\
\hline Any reported/detected adverse event & 75 & 37 & 38 \\
\hline Related to oseltamivir & 14 & 5 & 9 \\
\hline Any serious adverse event & 30 & 14 & 16 \\
\hline Related to oseltamivir & 1 & 0 & 1 \\
\hline Respiratory failure & 15 & 10 & 5 \\
\hline Diarrhoea & 11 & 2 & 9 \\
\hline Multi-organ failure & 6 & 3 & 1 \\
\hline Acute respiratory distress syndrome & 3 & 2 & 2 \\
\hline Pneumothorax & 3 & 1 & 1 \\
\hline Neutropenia & 3 & 2 & 1 \\
\hline Thrombocytosis & 3 & 3 & 2 \\
\hline Pyrexia & 2 & 1 & 2 \\
\hline Bronchitis & 2 & 0 & 11 \\
\hline Sepsis/septic shock & 3 & 1 & 2 \\
\hline Rash & 3 & 10 & 3 \\
\hline Other & 21 & & 2 \\
\hline
\end{tabular}

${ }^{*} \mathrm{P}=0.96$.

†Possibly, probably, or definitely related, as judged by principal investigator on site. 


\section{Figure}

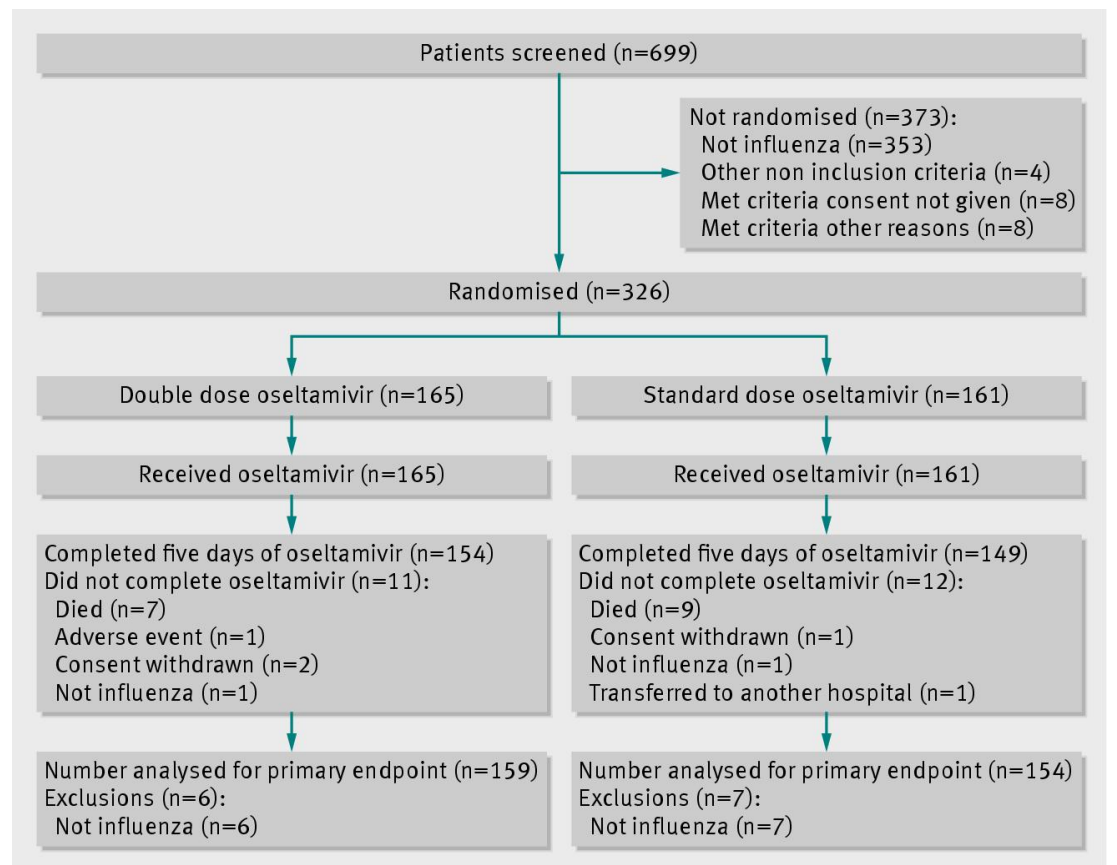

Trial profile of participants in study of double or standard dose oseltamivir for treatment of severe influenza 